\title{
The Role of Online Review and Buying Orientation to Increase Purchase Intention in Hospitality Industry
}

\author{
V U Tjhin ${ }^{1}$, A Permatasari ${ }^{2}$ \\ ${ }^{1,2}$ Information Systems Department, School of Information Systems, Universitas Bina \\ Nusantara, Jakarta, Indonesia \\ ${ }^{1}$ vtjhin@binus.edu, 2 angelina psw@binus.ac.id
}

\begin{abstract}
This study discusses the antecedents of online review and buying orientation on purchase intention. This study aims to explore the effect of online review and buying orientation towards purchase intention. Data was collected from a survey of 346 consumers, and SmartPLS was used as a Structural Equation Modeling (SEM) tool to analyze data. This study developed four hypotheses. The results of this study showed that buying orientation does not have a significant effect on purchase intention, type of review has a significant effect on purchase intention, brand orientation has a greater effect than quality orientation to purchase intention, and perceived informativeness has a greater effect than source credibility to purchase intention. The findings of this study differed from those of previous research. Consumers feel that their shopping orientation has no direct effect on purchase intention. However, the various opinions and information obtained by consumers through e-WOM help them to make purchasing decisions. In Indonesia, consumers are still more concerned with brands than quality. Similarly, information received by consumers is also more important than the credibility of the information source itself.
\end{abstract}

Keywords: Buying Orientation, Purchase Intention, Consumers

\section{INTRODUCTION}

Currently, the internet is no longer expensive and can only be used by certain groups. This has been proven by the increasing number of internet users in Indonesia. Based on a survey conducted by the Association of Indonesia Internet Service Providers [1], the number of internet users in Indonesia is always increasing. The increase in the number of internet users in 2014 to 2016 was 44.6 million people. The Association of Indonesia Internet Service Providers [1] projected that internet users in Indonesia in 2016 reached 132.7 million.

Based on the results of the polling from the Association of Internet Service users in Indonesia within 2016 and 2014, there is a significant increase in internet usage in Indonesia within 2 years. In 2016 , there are $98.6 \%$ or 130.8 million internet users in Indonesia know the internet as a place of buying and selling goods and services, then as many as $63.5 \%$ or 84.2 million had done online transactions and $3.4 \%$ or 4.5 million of them make transactions to book hotels [1].

The large number of internet users whose activities are to book rooms through internet sites coupled with the development of the hotel industry which continues to grow in line with the development of the business world, marked by the continued number of hotels in Indonesia with a variety of regional and international classification. This sector is one sector 
with a rapid development because Jakarta is a city of business and tourism. Until the third quarter of 2016 , there are at least 55,673 rooms or 352 hotels, originating primarily from the three-star and five-star hotels, with room occupancy rates in the range of $55-58 \%$. This condition is expected to increase to approximately 58,000 rooms by the end of 2016 . The number of foreign tourist arrivals reaches 5 million people in 2016, some of which enter through several main airports, namely Soekarno - Hatta, Ngurah Rai and Batam Airport. There are also several international destinations that are direct flights to China and Japan [2].

Along with the rapid growth of the hotel industry in Indonesia and the number of internet users in Indonesia, there is also a trend in hotel room reservation which is through online/internet which is expected to improve the service of guest book easily by the guest. The development of the internet today has become the daily needs of each individual. The Internet is a global network that brings together computer networks around the world that allow for communication and interaction with each other around the world. With the internet, users can find the desired information easily, quickly, and widely. Increasing numbers of internet users are also perceived by business owners who use information technology to facilitate their business activities. Nowadays many companies have marketed products or services offered by creating websites, blogs, e-mail, or social media called e-commerce or e-marketing and one of them is to provide online reviews on a purchasing website.

One that follows the e-marketing growth is the hospitality service field. Hospitality business cannot be separated from e-marketing by using Online Travel Agent services to be able to market and help companies in planning and developing their interactive marketing programs. Online Travel Agent is a travel agent that acts as a media promotion and online sales through travel websites. Today's society is more likely to use this Online Travel Agent as a medium of booking a room due to various conveniences and advantages that create a sense of satisfaction itself when ordering through Online Travel Agent. Now Online Travel Agent already has a very important role in the hospitality, that is by increasing Purchase Intention of a consumer. Consumers who will make purchases on an e-commerce site, usually they will see information about products from online reviews as a basis for assessing whether they will make a purchase.

Through the Online Travel Agent site the prospective guests or buyers can know the reviews about the experience of people who have been staying at the hotel, this causes purchase intention. According to [3], online reviews have become one of the important references when people book hotels online. It is a habit for consumers to comment online. Online reviews are an important source for both consumers and companies. For hotel managers and decision makers, online reviews reflect consumer opinions and hotel suggestions. The research relationship between online review and consumer purchase intention is very important. Several studies have concluded [4], that the higher consumer confidence in online will have an effect and result in higher consumer buying intentions online. Belief variable have a positive relationship and have a strong influence on intention of buying online.

To attract intention in purchasing, a company must know the factors influencing buying intention. Buying intention arises after an alternative evaluation process [5]. In the evaluation process, one will make a series of choices about the product to be purchased based on brand or intention and one of those factors is the shopping orientation owned by the consumers. Shopping orientation is one of the main indicators of making purchases online [4]. The concept of shopping orientation refers to a specific segment of the lifestyle that is expressed by various activities, intention and statements relevant to shopping [4]. 
The relationship between the decision of the prospective guest stay with the occupancy rate is very close. If the decision to stay high, then the impact on the occupancy rate is also high and the success of hotel management in selling the room can be said to succeed.But if the decision to stay a prospective guest is low, then the impact is the occupancy rate becomes low. Despite an increase in room occupancy rates but this is not significant, it remains an obstacle in the hospitality industry, as it can lead to a decrease in the hotel's profit when compared to its competitors' hotels.

Based on the above background, the researchers will develop a new construction to increase purchase intention through hospitality industry in Indonesia. The novelty of this research is type of review that will be examined as an antecedent that may contribute to increase purchase intention.

\section{LITERATURE REVIEW}

\subsection{E-WOM}

Increasing Internet and social networking is also important where word-of-mouth currently is not only an individual but can be in any form including the internet which is called electronic word-of-mouth [6]. The effectiveness of electronic word-of-mouth is more effective than Word of Mouth communication in the offline world, due to greater accessibility and high reach.

Electronic word-of-mouth (e-WOM) is a form of marketing communication that contains positive or negative statements made by potential consumers, consumers and former consumers about a product or company, available to many people or institutions through the internet. Electronic communications word-of-mouth has some of the same characteristics as traditional Word of Mouth communications. First, unlike traditional word-of-mouth, electronic word-of-mouth communications have unprecedented scalability and speed of diffusion.

In traditional word-of-mouth, various information occurs between small groups of people in sync or interconnected mode. Information in traditional word-of-mouth is usually exchanged in private conversation or dialogue. Information in the form of electronic word-ofmouth does not need to be exchanged at the same time when all communicators are present. For example, forum users can read and write other people's comments after the topic of conversation is made.

Second, unlike traditional word-of-mouth, electronic word-of-mouth communications are more fixed and accessible. Most text-based information presented on the internet is archived and thus will be available for unlimited time. Third, Electronic word-of-mouth communication is more measurable than traditional word-of-mouth. The format of Presentation, quantity, and persistence of electronic word-of-mouth communication have made them easier to observe. Word-of-mouth information available online is much more productive in quantity compared to information obtained from traditional contacts in the offline world.

Researchers can easily take many electronic word-of-mouth messages online and analyse their characteristics such as number of sentimental words used, message positions, message styles, and so on. The nature of electronic word-of-mouth where it cannot perform the assessment of the credibility of the communicator through the online reputation system. Nowadays, there are various ways in which consumers can exchange information. Internet users can do electronic word-of-mouth through various online channels, including blogs, 
micro blogs, emails, forums, virtual consumer communities, social networking sites and consumer review sites.

\subsection{Online Review}

Online review is currently widely used to help consumers make decisions [7]. It becomes important for marketers to understand the power of review and influence consumer behavior. The study shows that the review factor is crucial to encourage consumer purchasing decisions.

Basically, the reviews provided by consumers are based on previous experiences of what they feel, the value they get and what they see. The review site is divided into 2 as follows:

\subsubsection{Positive Review}

Reviews provided by consumers are positive in favour of what was seen, felt before. Positive assessment of the review can be seen from a good response, customer satisfaction and provide constructive feedback for consumers that have a great impact for the company.

\subsubsection{Negative Review.}

Reviews given by consumers are negative as there is a sense of disappointment about what they feel. Bad responses usually occur because consumers do not feel satisfaction, so it is not in accordance with what they have sacrificed.

\subsection{Buying Orientation}

According to [4], shopping orientation is defined as a general disposition of spending actions, this confirms that shopping orientation is one of the main indicators for making purchases online. The concept of shopping orientation refers to a lifestyle segment that is operationalized by various activities, intention and expression statements that are relevant to shopping.

In internet transactions, consumers will find information about the products sought by making the company name and brand trusted as the first step when making purchases online [8]. The study [9] stated that there is a significant influence of brand orientation on consumer intentions to make purchases online. Other studies have shown that a product that has a higher brand orientation seen from the company's name and brand will result in higher online purchases [4].

Quality orientation [10] is one of the things consumers love to buy is quality when choosing a store to shop as a satisfaction. In the context of online shopping, it is found that consumers who shop online with their own satisfaction will influence the consumer to determine the quality in the expenditure [11] In addition, other studies have shown that higher Quality Orientation will result in higher consumer online purchases [4].

\subsection{Purchase Intention}

Buying behavior occurs when consumers feel the urge to buy something at the same time without further evaluation [4]. So, it can be concluded that the orientation of purchase intention is the impetus to make a higher purchase will result in higher online purchase intentions towards a product. 
Purchase intention cannot be separated from consumer decision theory because intention is one of the final process of consumer purchase decision. Purchase intention is the stage before purchase decision in the process of making purchasing decisions. Buying intention is a desire that appears in the consumer of a product as the impact of a process of observation and learning to a product.

Online purchase intention is defined as a construction that gives power to the consumer's intention to buy online. Based on that opinion it can be concluded that buying intention arises because of the intention of the individual on the product being observed and accompanied by the ability to purchase the product. In addition, the observed and studied products will also be easier to obtain and other defines of buying intention. The study [12] suggested that buying intention is the consumer's prediction of the consumer's choice of which stores will they choose to make a purchase. Buying intention is the stage of respondent's tendency to act before the buying decision is implemented [13].

Search information for spending based on the impulses that occur in the consumer [14]. The first factor is based on the need, so the consumer will make purchasing based on the needs of the consumer itself. After that other influencing factor is the influence factor, this factor is divided into environmental factors and consumer itself. The last factor is based on experience. So, these three factors will generate intentions in consumer purchases.

\section{RESULT AND DISCUSSION}

The original conceptual model which described the relationship type of review and buying orientation is adopted and illustrated in Fig. 1. Initially type of review aspects relating to purchase intention still focused on online review. The research results stated that type of review as a source of information can increase the intention of consumer to buy. Similarly, buying orientation also has a strong influence in increasing consumer intention to buy.

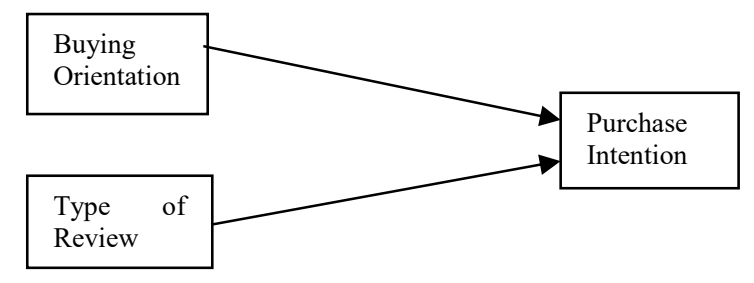

Figure1. Conceptual Model, adapted from Akar (2014) and Plotkina (2016).

Based on this argumentation, we hypothesize that

H1: Buying orientation has a significant effect on purchase intention.

$\mathrm{H} 2$ : Type of review has a significant effect on purchase intention.

H3: Brand orientation has a greater effect than quality orientation to purchase intention.

$\mathrm{H} 4$ :Perceived informativeness has a greater effect than source credibility to purchase intention

This study will apply two approaches, namely descriptive studies and research verification. This descriptive study will be conducted to obtain facts and characteristics of consumers who are confused. This research will require the complete information in the form of $5 \mathrm{~W}$ (why, when, who, what, where, and way). This verification study aims to examine the answers to some questions of research on buying orientation, type of review, and purchase intentions. The 
method used is the method descriptive survey and explanatory survey with individual analysis unit, namely the consumers who has purchased the hotel service through online transactions.

In this study, the population were consumers who have made hotel reservation transactions online. Approximately 11 percent of internet users in Indonesia (about 78 million people) are consumers who make online shopping transactions. This number reached approximately 8.58 million people and will be used as a population of this study. In determining the number of samples [15], when the population exceeds 500,000, the sample required in this study is 346 by using convenience sampling. Respondents consisted of $49 \%$ of men and $51 \%$ of women. The majority of respondents are aged between $10-34$ years as much as $84 \%$. The monthly income of the majority of respondents is about 3.3 million to 6.7 million rupiah.

From the survey results can be seen that the condition of type of review of hotels in Indonesia has the highest average score on consumer confidence to the review. Meanwhile, the perceived low level is still a lack of experience owned by reviewers. Other factors assessed for type of reviews are reliable reviews, easy-to-understand reviews, reviews that contain complete information, and reviews that are appropriate.

The condition of buying orientation owned by hotels in Indonesia is highest in the importance factor of hotel room standard compared with online booking of famous hotels. Priority to the image of the hotel is also considered very important in terms of hotel reservations rather than the priority of the hotel brand.

In terms of the intention of hotel bookings online, consumers believe that online reviews are the most considered factors compared to other factors such as ordering decisions and recommending to others. Most consumer bookings are in the 8-12 months range, where the majority of consumers have a holiday schedule of 1-2 times a year, especially in the middle and end of the year.

The results of the validity test of the research can be shown in Table 1. In Table 1, the value of Communality is the AVE value in all the variables studied in this research model is valid because AVE $>0.5$.

Table 1.Validity Testing.

\begin{tabular}{lcc}
\hline \multicolumn{1}{c}{ Variables } & Average Variance Extracted (AVE) & Result \\
\hline Purchase Intention & 0.506 & Valid \\
Shopping Orientation & 0.558 & Valid \\
Type of Review & 0.501 & Valid \\
\hline
\end{tabular}

The result of reliability testing can be seen in Table 2. In Table 2, the results of Cronbach's Alpha and Composite Reliability on all variables studied are reliable because Cronbach's Alpha and Composite Reliability on all variables studied in this research model has values above 0.7 .

Table 2. Reliability Testing.

\begin{tabular}{lcccc}
\hline \multicolumn{1}{c}{ Variables } & Cronbach's Alpha & rho_A & $\begin{array}{l}\text { Composite } \\
\text { Reliability }\end{array}$ & Result \\
\hline Purchase Intention & 0.802 & 0.808 & 0.858 & Reliable \\
Shopping Orientation & 0.736 & 0.739 & 0.835 & Reliable \\
Type of Review & 0.833 & 0.836 & 0.875 & Reliable \\
\hline
\end{tabular}


The result of first hypothesis testing in this study indicate that buying orientation does not have a significant effect on purchase intention. The test results can be seen in Table 3 . This means the first hypothesis is rejected and not supported by the data, where the value of Tstatistics is smaller than 1.96 and the value of $\mathrm{P}$ is greater than 0.050 .

The results of this study contradict the findings of previous studies [4]. Buying orientation is indeed one of the main indicators to make purchases online. However, the concept of shopping orientation refers more to certain lifestyle segments that are operationalized by various activities, intention, and expressions of opinion relevant to shopping.

Table 3. First Hypothesis Testing.

\begin{tabular}{cccccc}
\hline Variables & $\begin{array}{c}\text { Original } \\
\text { Sample }\end{array}$ & $\begin{array}{c}\text { Sample } \\
\text { Mean }\end{array}$ & $\begin{array}{c}\text { Standard } \\
\text { Deviation }\end{array}$ & T Stat & P Value \\
\hline Buying Orientation $\rightarrow$ Purchase Intention & 0.114 & 0.113 & 0.063 & 1.816 & 0.070 \\
\hline
\end{tabular}

The result of second hypothesis testing in this study indicate that type of review has a significant effect on purchase intention. The test results can be seen in Table 4 . This means the second hypothesis is accepted and supported by the data, where the value of T-statistics is greater than 1.96 and the value of $\mathrm{P}$ is smaller than 0.050 .

This is in line with the study result [7] that online reviews are widely used by consumers to help make purchasing decisions. It also provides assertiveness to service companies and marketers to use the power of reviews to consumers.

Table 4. Second Hypothesis Testing.

\begin{tabular}{cccccc}
\hline Variables & $\begin{array}{c}\text { Original } \\
\text { Sample }\end{array}$ & $\begin{array}{c}\text { Sample } \\
\text { Mean }\end{array}$ & $\begin{array}{c}\text { Standard } \\
\text { Deviation }\end{array}$ & T Stat P Value \\
\hline Type of Review $\rightarrow$ Purchase Intention & 0.590 & 0.592 & 0.058 & 10.249 & 0.000 \\
\hline
\end{tabular}

The result of third hypothesis testing in this study indicate that brand orientation has a greater effect than quality orientation to purchase intention. The test results can be seen in Table 5. This means the third hypothesis is accepted and supported by the data, where the value of T-statistics from Brand Orientation is greater than the value of T-statistics from Quality Orientation, and the $\mathrm{P}$ value from both T-statistics are greater than 0.050 .

Table 5. Third Hypothesis Testing.

\begin{tabular}{lccccc}
\hline \multicolumn{1}{c}{ Variables } & $\begin{array}{c}\text { Original } \\
\text { Sample }\end{array}$ & $\begin{array}{c}\text { Sample } \\
\text { Mean }\end{array}$ & $\begin{array}{c}\text { Standard } \\
\text { Deviation }\end{array}$ & T Stat P Value \\
\hline Brand Orientation $\rightarrow$ Buying Orientation & 0.807 & 0.807 & 0.026 & 30.895 & 0.000 \\
\hline Quality Orientation $\rightarrow$ Buying Orientation & 0.315 & 0.313 & 0.021 & 15.033 & 0.000 \\
\hline
\end{tabular}

The results of this study are in line with previous study [4], [8], [9]. The results of this study agreed that brand orientation has a greater role in company name and brand perspective, and this encourages consumers to make online purchases rather than quality orientation. However, quality-oriented consumers have higher expectations and satisfaction with their purchasing decisions. 
The result of fourth hypothesis testing in this study indicate that perceived informativeness has a greater effect than source credibility to purchase intention. The test results can be seen in Table 6. This means the fourth hypothesis is accepted and supported by the data, where the value of T-statistics from perceived informativeness is greater than the value of T-statistics from source credibility, and the $\mathrm{P}$ value from both $\mathrm{T}$-statistics are less than 0.050 .

Table 6. Fourth Hypothesis Testing.

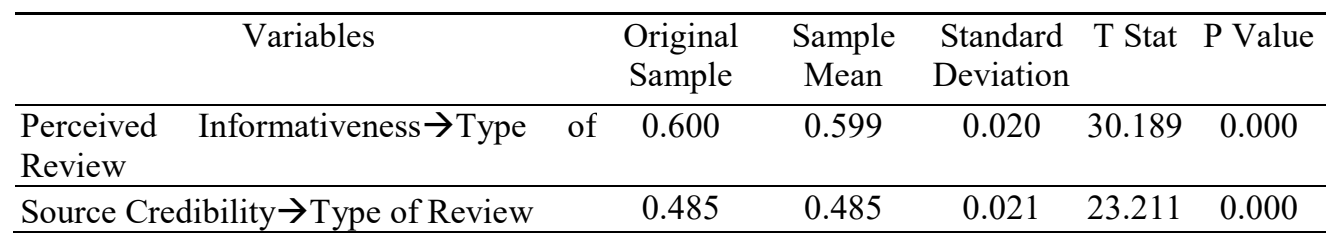

Previous studies stated that the dimensions of perceived informativeness and source credibility have an influence on purchasing intention. This study focuses on hotel services offering, so that the perceived consumer information is very important to determine the purchase decision. From various online reviews that are read and known by consumers, consumers can finally feel as if the service offered. Another factor is the online reviews that have credibility that makes consumers more confident about the reviews they get.

\section{CONCLUSIONS}

The main contribution of this study was the thought about online review and buying intention concepts in hospitality industry in Indonesia. This study will also explore further about the role of those antecedents towards consumer purchase intention. Recently consumers have had proneness to consider the opinions and recommendations about the products from their friends and family before they make a purchase decision. It makes the company should consider the role of E-WOM for their business. This factor is expected to improve the competitiveness of enterprises.

The level of consumer confusion is quite high in Indonesia. It would give effect to the decline in purchasing intentions. One contributing factor is that $69,89 \%$ percent of online consumers abandon shopping carts or cancel their purchase [16]. Thus, the features of hotel information conflicting and confusing should be minimized so that consumers do not become frustrated or confused.

The limitation of this research is the scope of the consumer coming from online hotel providers in Indonesia, such as Traveloka and Agoda, while there are many online hotel providers who are not observed in this study. For further research, it can be investigated whether the online reviews may increase e-loyalty for Indonesian consumers in hospitality industry.

\section{REFERENCES}

[1] APJII, Profil Pengguna Internet Indonesia 2016. Jakarta: Puskakom UI, 2017.

[2] PHRI, "Perhimpunan Hotel dan Restoran Indonesia," PHRI Online, 2016. [Online]. Available: http://www.phrionline.com/.

[3] Y. Yu, X. Guo, Y. Zhang, and H. Zhao, "Online Review Impacts on Hotel Online Booking Decision," in Proceedings of the 6th International Conference on Electronic, 
Mechanical, Information and Management Society, 2016.

[4] A. Thamizhvanan and M. J. Xavier, "Determinants of customers' online purchase intention: an empirical study in India," J. Indian Bus. Res., vol. 5, no. 1, pp. 17-32, Mar. 2013.

[5] P. T. Kotler, J. T. Bowen, and J. Makens, Marketing for Hospitality and Tourism. Upper Saddle River, NJ: Pearson Prentice, 2014.

[6] M. Reza Jalilvand and N. Samiei, "The effect of electronic word of mouth on brand image and purchase intention," Mark. Intell. Plan., vol. 30, no. 4, pp. 460-476, Jun. 2012.

[7] K. Z. K. Zhang, C. M. K. Cheung, and M. K. O. Lee, "Examining the moderating effect of inconsistent reviews and its gender differences on consumers' online shopping decision," Int. J. Inf. Manage., vol. 34, no. 2, pp. 89-98, Apr. 2014.

[8] M. R. Ward and M. J. Lee, "Internet shopping, consumer search and product branding," J. Prod. Brand Manag., vol. 9, no. 1, pp. 6-20, Feb. 2000.

[9] C. Jayawardhena, L. Tiu Wright, and C. Dennis, "Consumers online: intentions, orientations and segmentation," Int. J. Retail Distrib. Manag., vol. 35, no. 6, pp. 515526, May 2007.

[10] D. N. Bellenger and P. K. Korgaonkar, "Profile the recreational shopper," J. Retail., vol. 56, no. 3, pp. 77-92, 1980.

[11] K. C. Gehrt, N. Onzo, K. Fujita, and M. N. Rajan, "The Emergence of Internet Shopping in Japan: Identification of Shopping Orientation-Defined Segments," $J$. Mark. Theory Pract., vol. 15, no. 2, pp. 167-177, Apr. 2007.

[12] A. Nasermoadeli, K. C. Ling, and F. Maghnati, "Evaluating the Impacts of Customer Experience on Purchase Intention," Int. J. Bus. Manag., vol. 8, no. 6, Feb. 2013.

[13] T. C. Kinnear and J. R. Taylor, Marketing Research: An Applied Approach. New York: McGraw-Hill Inc., 1996.

[14] R. D. Blackwell, P. W. Miniard, and J. F. Engel, Consumer Behavior. Singapore: Cengage Learning Asia Pte Ltd, 2012.

[15] W. G. Zikmund, B. J. Babin, J. C. Carr, and M. Griffin, Business Research Methods, 9th ed. South-Western: Cengage Learning, 2013.

[16] Baymard Institute, "40 Cart Abandonment Rate Statistics," Baymard Institute, 2017. [Online]. Available: https://baymard.com/lists/cart-abandonment-rate. 